\title{
CORPORATE SOCIAL RESPONSIBILITY, FINANCING CONSTRAINTS AND CORPORATE SUSTAINABLE DEVELOPMENT
}

\author{
Youhua Wang \\ Panyapiwat Institute of Management, Nonthaburi, Thailand
}

Based on the resource-based theory and stakeholder theory, this paper uses the data on 540 A-share listed companies in Shanghai and Shenzhen stock exchanges from 2014 to 2019 to carry out an empirical test of the relationship between corporate social responsibility, financing constraints and corporate sustainable development by using Statal4 software. The author explains the internal influence mechanism of corporate social responsibility on corporate sustainable development. The results show that corporate social responsibility can inhibit financing constraints and promote the sustainable development of enterprises in the Chinese context. Financing constraints restrain sustainable development of enterprises. Financing constraints play an intermediary role in corporate social responsibility and sustainable development. The conclusion of the study provides new management insights for the practice of corporate social responsibility in China.

Keywords: corporate social responsibility; financial constraints; Chinese listed companies

\section{Introduction}

In China, corporate social responsibility issues such as environmental protection, food safety, labor rights and charitable giving receive a lot of attention among consumers and the general public overall. Corporate social responsibility has also become an important topic for many local scholars. The theory of shareholder supremacy holds that enterprises should pursue the maximization of economic benefits, and social responsibility is an additional economic burden.

However, Carroll (1979) creatively put forward the concept and connotation of social responsibility, which laid a theoretical foundation for the research in this area. Many scholars have found by now that there is a significant positive correlation between corporate social

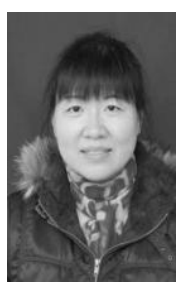

\section{Youhua Wang}

Chinese Graduate School, Panyapiwat Institute of Management, Nonthaburi,Thailand Research interests: financial market, bank customers' behavior, social responsibility of financial institutes, financial management 


\section{CORPORATE SOCIAL RESPONSIBILITY, FINANCING}

responsibility and long-term financial performance (McWilliams \& Siegel, 2000; Rynes et al., 2003; Surroca et al., 2010; Wang et al., 2016).

Freeman (1984) put forward the stakeholder theory that enterprises should bear the corresponding responsibility to stakeholders such as community environment, government and consumers. Later on, Michael Porter (2006) has found that corporate social responsibility can help enterprises maintain competitive advantage from the perspective of a corporate strategy. According to the resource-based theory, a good corporate social responsibility image is also an intangible resource, which can bring benefits to enterprises (Russo \& Fouts, 1997), and improve consumers' purchase behavior in relation to enterprises' products and/or services (Ma, 2011; Qi et al., 2016).

While China's economic development is entering the new normal, the economic structure is speeding up the optimization and upgrading. As the main body of market economic activities, sustainable development of enterprises is the key to achieving sustainable development within the social economy as a whole. At the same time, sustainable development of enterprises is also the microbasis for national sustainable development, which plays a vital role in changing the growth speed of macroeconomy.

At present, the research of scholars has been mainly focused on the relationship between CSR and financial performance, as well as on the relationship between CSR and corporate legitimacy, organizational reputation, customer loyalty, etc. Few scholars have studied the relationship between corporate social responsibility and corporate sustainable development, the relationship between financing constraints and corporate sustainable development, and the mediating mechanism of financing constraints between corporate social responsibility and corporate sustainable development.

In order to make up for this research gap, this study will be exploring the influence of corporate social responsibility on corporate sustainable development. On the one hand, the relationship between corporate social responsibility and corporate sustainable development is discussed and financing constraints are introduced into the research framework. The mediating role of financing constraints in the relationship between them is examined, and the literature research on the resource-based theory and stakeholder theory is thus enriched. On the other hand, the relationship between corporate social responsibility and sustainable development of enterprises and the relationship between financing constraints and sustainable development of enterprises is verified from an empirical perspective. All of these can provide theoretical basis and practical inspirations for the enterprises fulfilling their CSR promises.

\section{Literature review}

\section{Corporate social responsibility and financing constraints}

Corporate social responsibility is still a hot issue in the field of academic research. As a part of society, enterprises need to bear social responsibility. Stakeholder theory and resource-based theory both provide a theoretical basis for enterprises to take up social responsibility. Enterprises performing social responsibility can obtain a good corporate image, additional strategic resources and thus maintain competitive advantage.

In the real capital market, problems such as information asymmetry and agency cost lead to differences between external financing and internal financing of enterprises, thus forming financing constraints (Chen \& Xie, 2014). 
Corporate social responsibility is a special way to transmit the signal of good business development status to various stakeholders (Zhang \& Liang, 2012), thus enhancing investor confidence and reducing difficulties with company financing (Luo \& Li, 2015).

Corporate social responsibility data is an important information source for external investors to understand the company's situation (He et al., 2012). Voluntary disclosure of corporate social responsibility information affects the financing constraints of enterprises (Qian et al., 2017). Corporate social responsibility may help them to obtain support from the government and banks (Qian et al., 2016).

Companies with better social responsibility performance are more relaxed in terms of bank loan interest rate and loan terms than those without any social responsibility demonstrated (Goss \& Roberts, 2011). Also, social responsibility can meet the demands of various stakeholders, balance their expectations and requirements (Freedman \& Jaggi, 1988; Donaldson \& Preston, 1995), help with establishing a good relationship between enterprises and stakeholders, thus indirectly reducing financing costs and transaction costs (Feng et al., 2016). Finally, social responsibility information may be helpful when obtaining more external financing support, and also with solving various financing difficulties of enterprises (Wang \& Liu, 2018; Gao et al., 2017).

Based on the above analysis, this paper puts forward the following first assumption:

H1: Corporate social responsibility is negatively correlated with financing constraints.

\section{Corporate social responsibility and sustainable development}

Enterprise sustainable development in China means that in production and operations, we should not only consider the short-term profit goals and the market share, but also coordinate the relationship among shareholders, employees, consumers, suppliers, society, environment and other stakeholders, so as to realize the long-term sustainable profitability of enterprises, maintaining the competitive advantage.

As a non-market competition strategy, corporate social responsibility helps enterprises establish a good corporate image, expand advertising effects, increase the sense of identity among consumers and community members (Ma, 2011), and enhance corporate reputation (Li \& Zhang, 2010; Qi et al., 2016), build brand personality, enhance trust and loyalty to a brand (Huang et al., 2008), and transfer the external attention to important issues through donations (Gao et al., 2012).

Truth be told, in some cases CSR may also help with tax avoidance and covering up the internal problems through charitable donations (Li et al., 2016), so as to increase corporate profits (Carraseo \& Buendia, 2013) and ensure its long-term survival and development.

Enterprises can obtain resources and support by fulfilling their social responsibilities and maintaining long-term cooperative relations with various stakeholders (Zhang et al., 2013), accessing unique "social responsibility resources", improving the "imitation barrier", obtaining the first mover advantage (Barney, 1991), enhancing the integrity and effectiveness of enterprise internal control (Xia \& Hou, 2018), and improving the enterprise's business performance (Wu \& Deng, 2014). All of the above would surely have a positive effect on performance improvement and risk reduction (Zhou, 2020), which lays a good foundation for enterprises' sustainable development.

It can be stated that corporate social responsibility can provide innovative ways, new resource base and leading advantages for the sustainable development of enterprises. 


\section{CORPORATE SOCIAL RESPONSIBILITY, FINANCING}

To sum up, this paper puts forward the following assumption:

$\mathrm{H} 2$ : Corporate social responsibility is positively correlated with sustainable development of enterprises.

\section{Financing constraints and sustainable development of enterprises}

In the information age of economic globalization, the business competition environment is becoming increasingly fierce. If enterprises want to improve their profitability and change the existing development mode, they cannot go without sustainable development. However, sustainable development of enterprises needs to consume a considerable amount of various economic resources. Without financial support, enterprises cannot reach the state of efficient development, on the contrary, they will fall into economic difficulties.

Demir-Guc-Kunt and Maksimovic (1998) once demonstrated that external financing can significantly improve the growth rate of enterprises, and different financing methods adopted by enterprises and their own financing capacity will have a direct impact on the growth rate of enterprises.

Tan (2001) concluded that external financing has a positive effect on enterprise growth. Shen Kunrong and Zhang Cheng (2003) studied long-term financing and short-term financing respectively, and proposed that financing plays a decisive role in improving enterprise productivity and increasing income. Kong Xiang Zhen et al. (2020) believed that financing constraints increase operation difficulties and bankruptcy risks of enterprises, and reduce their behavioral motivation to produce high-quality products.

$\mathrm{Gu}$ Leilei and Wang Hongyu (2020) believed that financing constraints inhibit enterprises' technological innovation input, and the more serious the degree of financing constraints is, the more severe the degree of restraining technological innovation input will be, which is not conducive to enhancing the competitiveness of enterprises.

Xie Xueyan et al. (2020) believed that high-tech small and mid-sized enterprises face serious financing constraints, which have a negative inhibiting effect on their growth.

Li Fei (2020) has found that sustainable development of enterprises is closely related to their financing ability, and excessive financing constraints restrict $R \& D$ investment activities and expansion behaviors of enterprises, thus affecting their sustainable development.

Based on the above, this paper puts forward the following assumption:

H3: Financial constraints are negatively correlated with sustainable development of enterprises.

\section{The mediating role of financing constraints}

Corporate social responsibility can help with building corporate image, improved performance and competitiveness, it also increases the sense of identity among consumers and other community members, enhances corporate reputation, builds social responsibility brand personality, enhances brand trust and loyalty. Together this can bring in various advantages for future enterprise development. Financing plays a decisive role in improving enterprise productivity too.

Corporate social responsibility is a kind of signal transmission. It transmits the signal of good business development to all stakeholders. These positive signals can enhance investors' confidence, help them obtain the needed support from the government and banks, thus reducing difficulties with raising funds. Good reputation can also reduce financing costs and transaction costs, thus making it easier for enterprises to obtain loans and investment. 
Based on the above, this paper puts forward the following assumption:

H4: Financing constraints play an intermediary role between corporate social responsibility and corporate sustainable development.

\section{Research Design}

\section{Sample and data}

The sample used in this paper consists of the companies listed at Shanghai and Shenzhen stock exchange as all these companies are expected to issue CSR reports. In order to maintain the comparability of data and eliminate the influence of outliers, this study deals with the variables as follows:

Exclude financial companies, ST listed companies, monopoly companies, companies with incomplete financial data and missing corporate social responsibility data. The index data of the variables entered into the regression is within the percentiles from $1 \%$ to $99 \%$.

The CSR data comes from the CSR score database of RKS, a third-party rating agency. The time frame of the data used here is from 2014 to 2017. The data used for the variable of sustainable development of enterprises has been obtained from the CSMAR database. Considering the backward nature of the performance effect of corporate social responsibility, the data used is from 2016 to 2019.

Financing constraints are measured with the help of SA index data, 2014 to 2017. Finally, the financial data has been also obtained from the CSMAR database.

\section{Variable measurements}

Corporate sustainable development (CSD): the dynamic model of sustainable growth of Van Horn has been used here to measure the indicators of corporate sustainable development. Considering the postposition of the effect of corporate social responsibility, the indicators of corporate sustainable development adopt the data for two years later. Van Horn sustainable growth dynamic model can measure whether listed companies have long-term profitability and lasting competitive advantage.

Van Horn sustainable growth rate

$$
\begin{gathered}
(S G R)=(\text { net sales rate } * \text { total asset turnover rate } * \text { retained earnings rate } * \\
\text { equity multiplier }) /(1 \text {-net sales rate } * \text { total asset turnover rate * retained earnings rate * } \\
\text { equity multiplier })
\end{gathered}
$$

Corporate social responsibility (CSR): we are using the third-party rating agency's (RKS) corporate social responsibility score data to measure corporate social responsibility. Runling Global (RKS) is an authoritative third-party rating agency which measures corporate social responsibility in China.

With its independence, professionalism and open availability, the rating score has been recognized by many scholars and is widely used in research. The score data by RKS includes 15 first-level indicators and 65 second-level indicators.

The higher the score, the better the performance of corporate social responsibility.

Financing constraint (SA): this paper uses SA index to measure the variables of financing constraint, following Hadlock and Pierce (2010) and the KZ index to measure the degree of financing constraint. 


\section{CORPORATE SOCIAL RESPONSIBILITY, FINANCING}

The specific formula is as follows:

$$
S A=-0.737 * S I Z E+0.043 * \text { size-0.04*age }
$$

Among them, size and age respectively represent the scale of an enterprise and the establishment time of an enterprise, where

$$
\text { size }=\ln (\text { total assets of the enterprise (yuan) } / 1 \mathrm{mln})
$$

The greater the absolute value of this index, the greater the financing constraints on the enterprise.

Control variables: referring to the relevant research literature of the previous scholars, some factors affecting sustainable development of enterprises are selected as control variables, including:

(1) The size of a company (Size), which affects its financing decisions and is measured by the natural logarithm of assets;

(2) Enterprise age (Age) which is the difference of the year minus the year of establishment.

(3) Asset liability ratio (Lever) which is the ratio of total liabilities of the enterprise to its total asset value. The debt level reflects the risk-taking level of the enterprise which will affect its financing behavior, R\&D investments, innovations and other high-risk types of behavior.

(4) Return on assets (ROA) which is the ratio of net profit after tax to total assets. Return on assets is an indicator used to measure how much net profit is created per unit of assets.

Its calculation method is as follows the annual profit of the company is divided by the total asset value, and the return on assets is generally expressed in percentage.

(5) Total assets turnover rate (TATR) which is the ratio of net sales revenues to average total assets of an enterprise in a certain period, which is an index measuring the ratio between asset investment scale and sales level. The higher the turnover rate of total assets, the stronger the sales ability of enterprises, and the better the benefit of asset investment.

(6) Total asset growth rate (TAGR) which is the ratio of the growth in total assets of an enterprise this year to the total assets at the beginning of the year. This is the main index to analyze the capital accumulation ability and the development ability of an enterprise in that year.

Assets are the resources used by enterprises to obtain income, and also the guarantee for enterprises to repay their debts. Asset growth is an important aspect in the development of every enterprise. Enterprises with high development are able to maintain the stable growth of assets.

(7) YEAR, Year dummy variable.

(8) INDUS, Industry dummy variable.

\section{Regression model design}

To test the hypotheses, we have designed the following regression models: 


$$
\begin{aligned}
& \mathrm{SA}=\alpha+\beta 0 * \text { Controls }+\varepsilon \\
& \mathrm{SA}=\alpha+\beta 1 * \mathrm{CSR}+\beta 0 * \text { Controls }+\varepsilon \\
& \mathrm{CSD}=\alpha+\beta 0^{*} \text { Controls }+\varepsilon \\
& \mathrm{CSD}=\alpha+\beta 1 * \mathrm{CSR}+\beta 0 * \text { Controls }+\varepsilon \\
& \mathrm{CSD}=\alpha+\beta 2 * \mathrm{SA}+\beta 0 * \text { Controls }+\varepsilon \\
& \mathrm{CSD}=\alpha+\beta 1 * \mathrm{CSR}+\beta 2 * \mathrm{SA}+\beta 0 * \text { Controls }+\varepsilon
\end{aligned}
$$

Model (1) tests the influence of control variables on financing constraints.

Model (2) examines the impact of corporate social responsibility on financing constraints.

Model (3) tests the influence of control variables on the sustainable development of enterprises.

Model (4) examines the impact of corporate social responsibility on corporate sustainable development.

Model (5) tests the impact of financing constraints on the sustainable development of enterprises.

Model (6) tests the impact of corporate social responsibility and financing constraints on the sustainable development of enterprises. CSD is the sustainable development of enterprises, SA stands for financing constraints, CSR represents social responsibility of enterprises. The effect of heteroscedasticity has been avoided and robust standard error was adopted. Controls is the control variable, including Size, Age, Lever, ROA,TATR, TAGR and $\varepsilon$ is the residual.

\section{Results}

\section{Sample and description statistics}

Our study has selected 540 listed companies.

There are 336 state-owned holding enterprises and 204 non-state-owned holding enterprises in our final sample. In terms of industry, there are 61 IT companies and 38 real estate companies, 48 metal and non-metal manufacturing companies, 29 wholesale and retail companies, 36 electricity, gas and water production \& supply companies, 12 social service companies, 32 transportation and warehousing companies, 90 machinery, equipment, instrument manufacturing companies, 42 petroleum, chemistry and plastic companies, 31 pharmaceutical and biological product companies, 6 agriculture, forestry, animal husbandry, fishery companies, 25 food \& beverage companies, 28 mining companies, 13 garment \& fur manufacturing companies, 21 construction companies, 9 papermaking and printing companies, and 10 communication and culture companies.

The total of 2480 samples was observed for the years 2014-2019. The average asset liability ratio is $49.8 \%$, and the average corporate social responsibility is 41.92 , which is a low level. It shows that the level of corporate social responsibility is not high, and there is still a lot of room for improvement.

The standard deviation is 11.48 , because the gap between enterprises to fulfill corporate social responsibility is relatively large, so the variables may have heteroscedasticity. The descriptive statistics of other main variables of the sample are shown in Tab. 1. 
Table 1 - Description Statistics

(made by the author)

\begin{tabular}{|c|c|c|c|c|c|c|}
\hline Variable & sample value & mean & median & $\begin{array}{c}\text { standard } \\
\text { deviation }\end{array}$ & minimum & maximum \\
\hline CSR & 2160 & 41.921 & 39.457 & 11.484 & 17.347 & 87.948 \\
\hline SA & 2160 & -3.783 & -3.803 & 0.304 & -4.596 & -2.147 \\
\hline PC & 2160 & 0.650 & 1 & 0.407 & 0 & 0.034 \\
\hline Lever & 2160 & 0.498 & 0.508 & 0.197 & 0.995 \\
\hline TATR & 2160 & 0.601 & 0.505 & 0.413 & 0.008 & 3.281 \\
\hline ROA & 2160 & 0.056 & 0.049 & 0.056 & -0.663 & 0.484 \\
\hline TAGR & 2160 & 0.130 & 0.078 & 0.346 & -0.707 & 10.889 \\
\hline Size & 2160 & 9.524 & 9.445 & 1.453 & 5.737 & 14.693 \\
\hline Age & 2160 & 18.87 & 18 & 4.995 & 4 & 36 \\
\hline
\end{tabular}

\section{Correlation analysis}

Pearson correlation coefficient of each major variable is shown in Tab. 2. Only two of the correlation coefficients for each control variable are more than 0.5 . The correlation coefficient between Size and SA is 0.5540 .

Table 2 - Correlation Analysis

(made by the author)

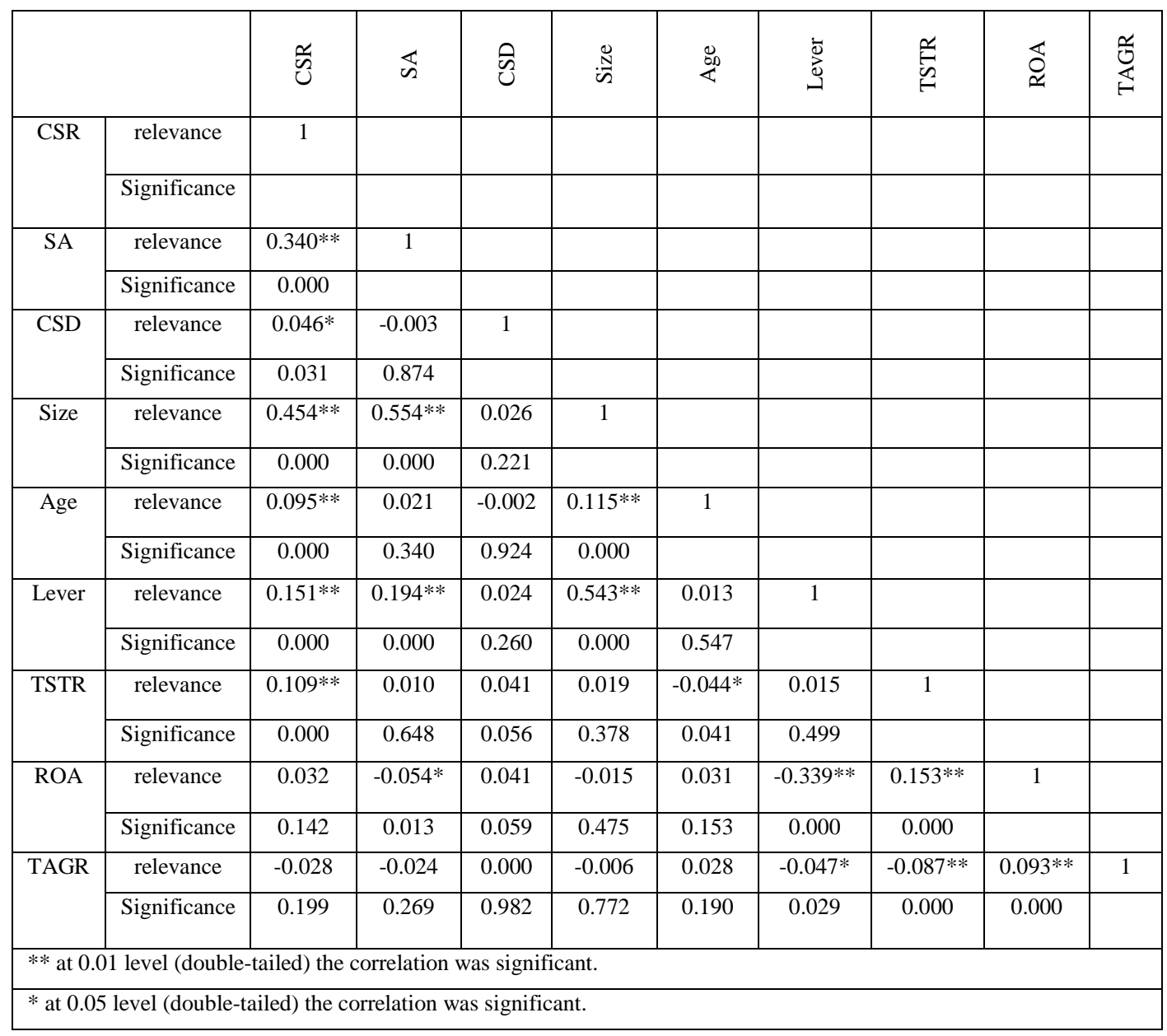


The correlation coefficient between Lever and Size is 0.543 , and the others are less than 0.5. Moreover, from the correlation coefficient of two variables, there is no multicollinearity problem, and the selection of samples and models is thus reasonable.

\section{Regression analysis}

Then, we have examined the relationship between corporate social responsibility and financing constraints. The regression test results for the equation model are shown in Tab. 3 . The coefficient of corporate social responsibility $(\beta 1=-0.002, \mathrm{P}=0.000<0.01)$ in model (2) is negative and significant at the level of $1 \%$. Thus, our test results support hypothesis H1. There is indeed a significant negative correlation between corporate social responsibility and financing constraints.

The next step is examining the relationship between corporate social responsibility and corporate sustainable development. The regression test results of the equation model are shown in Tab. 3.

The coefficient of corporate social responsibility $(\beta 1=0.03, \mathrm{P}=0.003<0.01)$ in model (4) is positive and significant at the level of $1 \%$. Therefore, our test results support the hypothesis $\mathrm{H} 2$. There is a significant positive correlation between corporate social responsibility and sustainable development.

Table 3 - Regression analysis results

\begin{tabular}{|c|c|c|c|c|c|c|c|c|c|c|c|c|c|}
\hline & \multicolumn{4}{|c|}{$\begin{array}{l}\text { Explained Variable: } \\
\text { financing constraint }\end{array}$} & \multicolumn{8}{|c|}{ Explained Variable: corporate sustainable development } \\
\hline & & \multicolumn{2}{|c|}{ model (1) } & \multicolumn{2}{|c|}{ model (2) } & \multicolumn{2}{|c|}{ model (3) } & \multicolumn{2}{|c|}{ model (4) } & \multicolumn{2}{|c|}{ model (5) } & \multicolumn{2}{|c|}{ model (6) } \\
\hline & & $\beta$ & Sig & $\beta$ & Sig & $\beta$ & Sig & $\beta$ & Sig & $\beta$ & Sig & $\beta$ & Sig \\
\hline constant & cons & -3.2 & 0.00 & -3.19 & 0.000 & 0.178 & 0.034 & 0.162 & 0.054 & -0.65 & 0.005 & -0.15 & 0.008 \\
\hline $\begin{array}{l}\text { Explanator } \\
\text { y Variables }\end{array}$ & CSR & & & -0.02 & 0.000 & & & 0.003 & 0.003 & & & 0.002 & 0.011 \\
\hline $\begin{array}{l}\text { Mediating } \\
\text { variables }\end{array}$ & SA & & & & & & & & & -0.26 & 0.000 & -0.24 & 0.000 \\
\hline \multirow{8}{*}{$\begin{array}{c}\text { control } \\
\text { variables }\end{array}$} & Age & 0.025 & 0.01 & 0.026 & 0.001 & -0.03 & 0.117 & -0.03 & 0.113 & -0.02 & 0.202 & 0.010 & 0.188 \\
\hline & Size & -0.07 & 0.00 & -0.06 & 0.000 & -0.01 & 0.362 & -0.02 & 0.057 & -0.03 & 0.010 & -0.01 & 0.002 \\
\hline & Lever & 0.133 & 0.0 & 0.122 & 0.000 & -0.03 & 0.701 & -0.02 & 0.810 & 0.004 & 0.952 & 0.153 & 0.885 \\
\hline & TSTR & 0.023 & 0.11 & 0.021 & 0.163 & 0.059 & 0.099 & 0.062 & 0.087 & 0.065 & 0.075 & 0.139 & 0.070 \\
\hline & ROA & -0.01 & 0.77 & -0.02 & 0.631 & -0.32 & 0.183 & -0.31 & 0.189 & -0.32 & 0.172 & 0.145 & 0.177 \\
\hline & TAGR & 0.018 & 0.01 & 0.016 & 0.022 & 0.001 & 0.915 & 0.003 & 0.640 & 0.005 & 0.361 & 0.018 & 0.253 \\
\hline & YEAR & \multicolumn{2}{|c|}{ Control } & \multicolumn{2}{|c|}{ Control } & \multicolumn{2}{|c|}{ Control } & \multicolumn{2}{|c|}{ Control } & \multicolumn{2}{|c|}{ Control } & \multicolumn{2}{|c|}{ Control } \\
\hline & INDUS & \multicolumn{2}{|c|}{ Control } & \multicolumn{2}{|c|}{ Control } & \multicolumn{2}{|c|}{ Control } & \multicolumn{2}{|c|}{ Control } & \multicolumn{2}{|c|}{ Control } & \multicolumn{2}{|c|}{ Control } \\
\hline
\end{tabular}

Next we have examined the relationship between financing constraints and sustainable development of enterprises. The regression test results of the equation model are shown in Tab. 3. The coefficient of corporate social responsibility $(\beta 2=-.259, \mathrm{P}=0.000<0.01)$ in model (5) is negative and significant at the level of $1 \%$.

Thus, the test results support the hypothesis $\mathrm{H} 3$. There is a significant negative correlation between financing constraints and sustainable development of enterprises.

Finally, we have examined the relationship between corporate social responsibility, financing constraints and sustainable development (the test of the intermediary role of financing constraints). The regression test results of this equation model are also shown in Tab. 3. 


\section{CORPORATE SOCIAL RESPONSIBILITY, FINANCING}

In model (6), the coefficient of corporate social responsibility $(\beta 1=0.002, \mathrm{P}=0.011<$ $0.05)$ is positive and significant at the level of $5 \%$, while the coefficient of financing constraint is negative and significant $(\beta 2=-0.235, \mathrm{P}=0.00<0.01)$.

According to Wen Zhonglin's three-step test method of mediating effect, combining model (2), model (4) and model (6), we can infer that the test results support hypothesis H4, which shows that financing constraints play a partial mediating role in corporate social responsibility and corporate sustainable development.

Therefore, our test results support the hypothesis H1, that is, the better the quality of corporate social responsibility performance, the smaller the financing constraints. The test results also support hypothesis $\mathrm{H} 2$, that is, better the quality of corporate social responsibility performance can promote sustainable development of enterprises.

The test results support the hypothesis $\mathrm{H} 3$, that is, financing constraints tend to inhibit sustainable development of enterprises. The test results support the hypothesis H4, that is, financing constraints play a partial mediating role in corporate social responsibility and corporate sustainable development.

\section{Robustness tests}

HeXun is an independent financial portal website in China with certain authority. It evaluates corporate social responsibility of the listed companies in China through expert scoring based on their annual financial reports and independent social responsibility reports released by the companies.

The CSR data coming from the Hexun network was used to replace the CSR data coming from the CSR score database of RKS. The hierarchical regression analysis is carried out again. The results are basically consistent with the previous ones, which verify the reliability and robustness of the results obtained in the course of this study.

\section{Summary and discussion}

Based on the resource-based theory and stakeholder theory, this paper empirically tests the relationship between corporate social responsibility, financing constraints and sustainable development of enterprises, and also discusses the impact mechanism of corporate social responsibility on sustainable development of enterprises.

The results show that: (1) the better the quality of corporate social responsibility performance, the smaller the financing constraints; (2) financing constraints inhibit sustainable development of enterprises; (3) Better quality of corporate social responsibility performance can promote sustainable development of enterprises; (4) financing constraints play a partial intermediary role in the relationship between corporate social responsibility and sustainable development.

The main theoretical contributions are as follows:

First of all, corporate social responsibility is an investment and an intangible resource of enterprises. Application of this intangible resource to products and services can meet the requirements of stakeholders such as the government, suppliers and customers. If corporate social responsibility is well performed, it is conducive to enterprise financing and tends to reduce financing constraints, thus promoting sustainable development of enterprises. This verifies the effectiveness of corporate social responsibility The theoretical model of the 
relationship between corporate social responsibility, financing constraints and sustainable development enriches the resource-based theory and stakeholder interest theory.

Secondly, our study verifies the impact of financial constraints on the sustainable development of enterprises and the mediating effect of financial constraints on the relationship between corporate social responsibility and sustainable development of enterprises, thus enriching the research on the mediating mechanism of corporate social responsibility.

In addition, it has some practical implications for Chinese enterprise management. Enterprises should actively fulfill their social responsibility, establish the concept of corporate social responsibility, and create a culture of social responsibility within enterprises; the government and relevant departments in particular should give full play to their rights and functions, strengthen the supervision of corporate social responsibility, and improve the construction of a corporate social responsibility system. These practices are beneficial for enterprises that aim to fulfill and bear social responsibilities, establish a good corporate image, standardize their management behavior, reduce financing constraints, and promote sustainable development of enterprises.

\section{References}

Barney, J. (1991). Firm resources and sustained competitive advantage. Advances in Strategic Management, 17(1), 99-120.

Carrasco, M.I. \& Buendia, M.I. (2013). Corporate social responsibility: a crossroad between changing values, innovation and internationalization. European Journal of International Management, 3, 295-314.

Carroll, A.B. (1991). The pyramid of corporate social responsibility: Toward the moral management of organizational stakeholders. Business Horizons, 34(4), 39-48.

Chen, J.L. \& Xie, Q.J. (2014). Social responsibility, property rights and financing constraints. Journal of Nanjing Institute of Audit, 11 (03), 96-103.

Demirguc, K. \& Maksimovic,V. (1998). Law, Finance, and Firm Growth. Journal of Finance, 53(6).

Donaldson, T. \& Preston, L.E. (1995). The Stakeholder Theory of the Corporation: Concepts, Evidence and Implications. Academy of Management Review, 20(1), 65-91.

Feng, L.Y., Xiao, X., Zhao, T.J. \& Zhang, J. (2016). Social performance, information disclosure and financing constraints: Empirical Evidence from Chinese listed companies. Journal of Beijing Jiaotong University, 15 (01), 74-86.

Freedman, M. \& Jaggi, B. (1988). An Analysis of the Association between Pollution Disclosure and Economic Performance. Accounting, (2), 43-58.

Freeman, R. (1984). Strategic Management: A Stakeholder-Based Approach. Pitman: Boston.

Gao, F.Y., Tian, G.L. \& Wang, X. (2017). Can small and medium-sized enterprises fulfill their social responsibilities to alleviate financing constraints? Journal of science and technology management, 38 (6), 133-143.

Gao, Y.Q., Chen, Y.J. \& Zhang, Y.J. (2012). Red scarf or green scarf: A Study on the motivation of charitable donation of private enterprises. Management world, 8, 106-114. 


\section{CORPORATE SOCIAL RESPONSIBILITY, FINANCING}

Goss, A. \& Roberts, G.S. (2011). The impact of corporate social responsibility on the cost of bank loans. Journal of Banking \& Finance, 35(7), 1794-1810.

Gu, L.L. \& Wang, H.Y. (2020). Social trust, financing constraints and enterprise innovation. Economist, (11), 39-50.

Hadlock, C.J. \& Pierce, J.R. (2010). New Evidence on Measuring Financial Constraint: Moving Beyond the KZ Index. Review of Financial Studies, 23(5).

He, X.J., Xiao, T.S. \& Chen, X.Y. (2012). Corporate social responsibility information disclosure and corporate financing constraints. Financial research, 38 (8), 60-71.

Huang, M.X., Li, X.L. \& Zhu, H.W. (2008). Analysis of the phenomenon that enterprises are forced to donate: is it the public's "unreasonable" or the enterprise's "unscrupulous"? Management world, 10, 115-126.

Kong, X.Z., Qin, B.Y. \& Liu, Z.X. (2020). Financing constraints and quality upgrading of export products of Chinese manufacturing enterprises. World Economic Research, 4, 17-29.

Li, F., Zhu, Y.M. \& Zhang, Y.R. (2020). The impact of industrial policies and financing constraints on the sustainable development of enterprises under the new normal. Contemporary economy, $1,5-23$.

Li, H.Q. \& Zhang, Z.G. (2010). An empirical study on the impact of CSR on corporate reputation and customer loyalty. Nankai management review, 1, 90-98.

Li, W.A., Wang, P.C. \& Xu, Y.K. (2015). Charitable donation, political connection and debt financing resource exchange behavior between private enterprises and the government. Nankai Management Review, 18 (01), 4-14.

Li, Z.F., Tang, X.D. \& Lian, Y.J. (2016). The mystery of social responsibility deviation of Chinese private enterprises. Management world, 9, 136-148.

Luo, S.M. \& Li, M.H. (2015). Social responsibility information disclosure, Auditor Selection and financing constraints - new evidence from A-share market. Journal of Shanxi University of Finance and economics, 37 (2), 105-115.

Ma, L.L. (2011). The influence mechanism of corporate social responsibility on consumers' purchase intention. Management world, 5, 120-126.

McWilliams, A. \& Siegel, D.(2000).Corporate Social Responsibility and Financial Performance: Correlation or Misspecification? Strategic Management Journal, 21(5), 603-609.

Porter, M.E. \& Kramer, M.R. (2006). Strategy and society: the link between competitive advantage and corporate social responsibility. Harvard Business Review, 84(12), 78.

Qi, L.Y., Zhang, B.B. \& Guo, Y.N. (2016). The impact of consumers' corporate social responsibility identity on purchase intention. Scientific research management, 5, 112-121.

Qi, L.Y., Zhang, B.B. \& Guo, Y.N. (2016). The influence of consumers' corporate social responsibility recognition on purchase intention. Scientific Research Management, 37 (5), 112121.

Qian, M., Xu, G.H. \& Shen, Y. (2016). Social responsibility information disclosure, accounting conservatism and financing constraints: from the perspective of property heterogeneity. Accounting research, 5, 9-17.

Qian, M., Xu, G.H., Shen, Y. \& Dou, X.C. (2017). Dynamic relationship between voluntary social responsibility information disclosure and financing constraints of private enterprises. Management review, 29 (12), 163-174. 
Russo, M.V. \& Fouts, P.A. (1997). A Resource-Based Perspective on Corporate Environmental Performance and Profitability. Academy of Management Journal, 40(4), 534-559.

Rynes, S.L., Schmidt, F.L. \& Orlitzky, M. (2003). Corporate Social and Financial Performance: A Meta-analysis. Organization Studies, 24(4), 403-441.

Shen, K.R. \& Zhang, C. (2003). External financing and growth of Chinese Enterprises: a case study of listed companies. Management world, 7, 120-126.

Surroca, J., Tribo, J.A. \& Waddock, S. (2010). Corporate responsibility and financial performance: the role of intangible resources. Strategic Management Journal, 31(5), 463-490.

Tan, R.Y. (2001). An Empirical Study on the relationship between external financing and enterprise growth. Securities market guide, 2, 23-26.

Wang, H., Tong, L. \& Takeuchi, R.T.A.P. (2016). Thematic Issue on Corporate Social Responsibility: An overview and new research directions. Academy of Management Journal, 59(3), 534-544.

Wang, Y.M. \& Liu, Y.M. (2018). Charitable donations, political connections and private enterprise financing behavior. Financial research, 6, 54-69.

Wu, L. \& Deng, Y.Y. (2014). Analysis of the impact of fulfilling social responsibility on the sustainable development of Enterprises Empirical Evidence from China's A-share listed companies. Journal of Hubei University of Technology, 31(3), 39-43.

Xia, B. \& Hou, X.X. (2018). Enterprise internal control, social responsibility and sustainable development ability. Journal of Xi'an University of Technology, 34(2), 246-252.

Xie, X.Y., Guo, Y.Y., Zhu, X.Y. \& Kang, W.L. (2018). Empirical analysis on the relationship between financing constraints, entrepreneurship and enterprise performance. Statistics and decision, 34(20), 180-184.

Zhang, Z.G., Jin, X.C. \& Li, G.Q. (2013). An Empirical Study on the intertemporal interaction between corporate social responsibility and financial performance. Accounting research, 8, 3239.

Zhang, Z.G., Liang, Z.G. \& Yin, K.G. (2012). Research on corporate social responsibility from the perspective of stakeholders. China soft science, 2, 139-146.

Zhou, F.Z., Jin, Y.P. \& He, Z.F. (2020). The impact of corporate social responsibility on corporate performance and risk: evidence from China's A-share listed companies. Technical economy, 39 (8), 119-129.

Paper submitted

Paper accepted for publishing

Paper published online
11 December 2020

20 January 2021

30 November 2021 